\title{
Role of Self Help Groups in Empowering Rural Women in India
}

\author{
Dr. Mohini Agrawal
}

\begin{abstract}
Women's economic empowerment refers to the ability for women to enjoy their rights to control and benefit from resources, assets, income and their own time, as well as the ability to manage risk and improve their economic status and wellbeing. It can be achieved through political power, education, employment and Self help groups. Among these, self help groups dominate and fruitful success of the women empowerment. Self Help Groups mainly concerned with the enlistment of the women in the society through, social, economical aspects. Self Help Groups not only mobilize micro finance and provide micro credit to the needed members but also it provides self employment training, awareness programme, promote the leadership qualities and confidential life to its members.

This paper is concerned with empowerment of rural women and the role of Self Help Groups in providing economic empowerment to the women of rural areas of India.
\end{abstract}

Keywords - Women, SHGs, India, Empowerment.

\section{INTRODUCTION}

$\mathrm{T}$ HE word empowerment is defined as the process by which women take control and ownership of their choices. Empowerment is a process of awareness and capacity building leading to greater participation, to greater decision making power and control and transformative action. Empowerment of women signifies harnessing women power by conscientising their tremendous potential and encouraging them to work towards attaining a dignified and satisfying way of life through confidence and competence as person with self-respect, rights and responsibilities. The core elements of empowerment have been defined as agency, awareness of gendered power structures, self-esteem, and self-confidence. Empowerment as a concept was introduced at the International Women's Conference at Nairobi in 1985. The conference defined empowerment as "A redistribution of social power and control of resources in favour of women. It is "the process of challenging existing power relations and of gaining greater control over the sources of power". Empowerment is a multifaceted process which encompasses many aspects i.e. enhancing awareness, increasing access to resources of economic, social and political etc."In recent years women empowerment has become a subject of great concern for the nations all over the world especially in poor and developing countries. The impact of globalization is seen eventually on

Dr Mohini Agrawal is an Assoc. Professor of Economics at MMV PG College, Kanpur (India) position of women in some form or other in most of the developing countries with the variation of degree. The United Nations has also strived hard in an incredible way to draw the due attention of the World Community on this issue in the past years. Women Empowerment refers to an increase in the strength of women such as spiritual, political, social or economic. The most common explanation of "Women"s Empowerment" is the ability to excise full control over one "s actions. Thus, women empowerment occurs in real sense when women achieve increased control and participation in decision making that leads to their better access to resources it often involves the empowered developing confidence in their own capacities. WOMEN EMPOWERMENT IN INDIA The year 2001had been declared by the Government of India as "Women"s Empowerment Year" to focus on a vision where women are equal partners like men". Because the Constitution of India grants equality to women in various fields of life. In the past, the position of women was miserable in the society and even women were not ready to undertake any assignment or job due to many reasons like fear, shyness, male dominance in the society and purda system but time has been changed now. Women of today are not like the early days. Now, they are always ready to come forward and want more economic independence, their own identity, achievements, equal status in the society and greater freedom. And Government of India has provided for Self Help Groups (SHGs) to them so that proper attention should be given to their economic independence through self-employment, entrepreneurial development and wellbeing that ultimately leads to its contribution. SHGs have been emerged as a powerful instrument in order to alleviate poverty and for the empowerment of women in the rural economy. SHGs through the network of commercial banks, cooperative banks, regional rural banks, NABARD and NGO's has been largely supply driven and a recent approach in the provision of financial services to the poor and further upgrading their status in the society. In this way, SHGs are important not only to reduce rural poverty, to promote rural savings but also to increase gainful employment. Keeping this in mind, the present study is to study the growth of SHGs and to analyse the current position of women empowerment and study the economic improvement of women after their joining SHGs. The information for the study has been collected from secondary sources i.e. various books, Journals, newspapers, published literature, websites, and annual reports.

Self-Help Group (SHG) is a small voluntary association of 
poor people, preferably from the same socio-economic background. They come together for the purpose of solving their common problems through self-help and mutual help. The SHG promotes small savings among its members. The savings are kept with a bank. Following are the advantages of SHG's:-

- An economically poor individual gains strength as part of a group.

- Besides, financing through SHGs reduces transaction costs for both lenders and borrowers.

- While lenders have to handle only a single SHG account instead of a large number of small-sized individual accounts, borrowers as part of an SHG cut down expenses on travel (to and from the branch and other places) for completing paper work and on the loss of workdays in canvassing for loans.

- Where successful, SHGs have significantly empowered poor people, especially women, in rural areas.

- SHGs have helped immensely in reducing the influence of informal lenders in rural areas.

- Many big corporate houses are also promoting SHGs at many places in India.

- SHGs help borrowers overcome the problem of lack of collateral.

\section{A. Self-help groups and micro-enterprise development}

- After the training, the SHG members started microsavings and credit activities, as each member was asked to contribute at least Rs. 50 per month ( 1 dollar), which could then be used for internal micro-loans (i.e., to members within the same group). Loans are used for a variety of purposes including micro-income generating activities. Examples are the purchase of bullocks, sheep, poultry, goats and sewing machines. The women repay the money in monthly installments with interest, so that the money in the revolving fund can be used continuously.

- Because the amount of money that SHG members of a newly formed group can save each month is very small, it became very clear early on that there was a need for additional funding from external sources to increase the amount of money that would be available for micro-loans. For the first 5 groups that READ has formed, READ was soon able to mobilize a revolving fund from the DWCRA (Development of Women and Children in Rural Areas) agency, for a total amount of 600 US dollars per group to expand the credit activities which they had already formed from their own savings.

- Some of the SHG groups utilized their skills and the loan to develop group activities.

One has to believe that the progress of any nation is inevitably linked with social and economical plight of women in that particular country. Empowerment by way of participation in SHG can developing nations. The underlying principle of SHG is to provide to the poorest of the poor and to achieve empowerment. Self Help Group (SHG) is a process by which a large group of women $(10-20)$, with common objectives are facilitated to come together voluntarily to participate in the development activities such as saving, credit and income generation thereby ensuring economic independence. SHG phenomenon definitely brings group consciousness among women, sense of belongingness, adequate self confidence. In fact, what she cannot achieve as an individual, can accomplish as a member of group with sufficient understanding about her own rights, roles, privileges and responsibilities as a dignified member of society in par with man. When she becomes a member of SHG, her sense of public participation, enlarged horizon of social activities, high self-esteem, self-respect and fulfillment in life expands and enhances the quality of status of women as participants, decision makers and beneficiaries in the democratic, economic social and cultural spheres of life. In other words, we can say that SHG is an effective instrument to empower women socially and economically which ultimately contributes in the overall development of the country like India wherein still large segment of women population are underprivileged, illiterate, exploited and deprived of basic rights of social and economic spectrum.

\section{CONCLUSION}

SHGs have been identified as a way to alleviate poverty and women empowerment. And women empowerment aims at realizing their identities, power and potentiality in all spheres of lives. But the real empowerment is possible only when a woman has increased access to economic resources, more confidence and self motivation, more strength, more recognition and say in the family matters and more involvement through participation. Although it is a gradual and consistent process, but women should build their mindset for taking additional effort willingly for their overall development. SHGs have the potential to have an impact on women empowerment. Self Help Group concept has been mooted along the rural and semi urban women to improve their living conditions. Even though SHG concept is applicable to men also in our country, it has been more successful only among women. To reduce poverty by enabling the poor household to access gainful self employment and skilled wage employment opportunities, resulting in appreciable improvement in their livelihood on a sustainable basis, through building strong grass-root institutions of the poor (SHGs) is now the main motive of the most of the employment schemes. Thus SHGs have been showing the way ahead to alleviate the poverty of India alongwith women empowerment.

\section{REFERENCES}

[1] Abdul Raheem, aphyasmeen and solthana kissan (2007)

[2] World empowerment of women thought self help group a view sakthi sugans Ltd, p. 48 Arjun Y., Pangannavar (2010)

[3] "Women SHG Programmes and Rural Poverty: A Micro Study" Southern Economist, pp47-50 Chandra P., Parida and Anushree Sinha (2010)

[4] "Performance and Sustainability of Self Help Groups in India: A Gender Perspective" Asian Development Review, Vol.-27(1), pp80-103. Jayaraman R. (2005) 
Int'I Conf. on Law, Education, Business and Corporate Social Responsibilities (LEBCSR-17) Sept. 4-5, 2017 Budapest (Hungary)

[5] "Performance Analysis of Fisherwomen SHGs in Tamilnadu" final report submitted to NABARD, pp1-63. Jayanthi.C "Empowering Women". Yojana, June 2001. 